\title{
Child Migration and Dropping Out of Basic School in Ghana: The Case of Children in a Fishing Community
}

\author{
Eric Daniel Ananga \\ National Centre for Research into Basic Education (NCRIBE), University of Education, Winneba, Ghana \\ Email: edananga@gmail.com \\ Received September 30 ${ }^{\text {th }}$, 2012; revised April 28 $8^{\text {th }}$, 2013; accepted May $9^{\text {th }}, 2013$
}

\begin{abstract}
Copyright ( 2013 Eric Daniel Ananga. This is an open access article distributed under the Creative Commons Attribution License, which permits unrestricted use, distribution, and reproduction in any medium, provided the original work is properly cited.
\end{abstract}

\begin{abstract}
The government of Ghana's effort on increasing access to basic education led to removal of school fees, introduction of capitation grants, school feeding and free school uniforms. While such moves have been applauded leading to improved access, child migration remains a barrier to educational access for children living in fishing communities in Ghana. This paper presents the experiences of schoolchildren who drop out of school as a result of child labour and seasonal migration. The central questions of the study are how and why migration acts as a barrier to education of children who had initial access. The paper presents in-depth analysis of qualitative data. The findings presented in the paper demonstrate that children enroll and attend school until they begin to migrate during mid-school sessions resulting in their exclusion from basic school. The paper concludes by highlighting some policy implications of children's seasonal migration during school sessions and access to basic school in Ghana.
\end{abstract}

Keywords: Child Migration; School Dropout; Children; Child Labour

\section{Introduction}

Factors such as the cost of education and other socio-cultural issues are cited in dropout literature as causes. The reasons why pupils are unable to complete basic education in developing countries have been attributed to structural factors at household, school and society levels (Colclough et al., 2003; Eie, 2003, cited in Wikan n.d.; Hunt, 2008). The argument that most children in Africa are enrolled in school, but that the real problem concerns children dropping out of school has been raised (Dumas et al., 2004; Lewin, 2007). Ensuring children enrollment in school is one thing, but whether they will complete their education is another issue altogether.

In Ghana, access to primary education has grown over the years and Gross Enrolment Rates are now above 95\% (MOESS, 2007). According to official statistics, $85 \%$ of children of school going age went to school (86.3\% boys and $83.6 \%$ girls) in 2001 and between that period and 2006, gross enrolments is reported to have reached 90\% (MOESS, 2006). Basic education (kindergarten and grades 1 - 9) is compulsory in Ghana's education system. While basic school enrolment in Ghana has improved significantly in recent years, one major challenge facing it has been high levels of drop out (MOESS, 2007). Over 20\% of school going children in Ghana have either dropped out or never enrolled in school at primary level (Ampiah \& Adu-Yeboah, 2009). Reports on the state of education in Ghana by Akyeampong et al. (2007) and other studies (see GSS, 2003; Hashim, 2004; MOESS, 2007, 2008) confirm the reality of school dropout in Ghana's basic school system. In 2006, noncompletion rates stood at $15 \%$ and $35 \%$ for primary and junior high school (JHS) levels ${ }^{1}$ respectively (MOESS, 2007).
To explain what hinders some children participation in schooling, issues of poverty, location, gender and age have been identified to have interacted with seasonal obligations and child labour (Hunt, 2008). Studies have found that there is a trade-off between child labour and child schooling (see Heady, 2003; Rosati \& Rossi, 2007). Although there is a growing body of interest in the influence of child labour and child migration on children's schooling, there have been relatively few empirical studies in Ghana focusing on how seasonal migration clashes with school calendar (Akyeampong et al., 2007). Not much is understood about independent child migrants (Edmonds \& Shreta, 2009), in relation to school attendance patterns (Ananga, 2011). The purpose of the study is to fill this knowledge void by exploring the influence of seasonal child migration on school attendance in an empirical setting. The data used in this paper draws on data from the authors' doctoral thesis. In this paper, I highlight the accounts of children who migrated seasonally to work to shed light on clashes between child labour, seasonal child migration and school calendar in Ghana. The key question the study explored was how and why migration shape school attendance and school drop out?

\section{Dropout Literature: Child Labour, Child Migration and Access to School}

While education is considered in a positive light and migration is assumed to interfere with children's ability to access education, some research findings suggests an ambiguous and

\footnotetext{
${ }^{1}$ Basic education in Ghana comprises 2 years of pre-school, 6 of years primary schooling and 3 years junior high school for children who should enter at age 4,6 and 12 respectively.
} 
complex picture, showing both positive and negative links between child migration and access to education (Hashim, 2005). The literature highlights how child labour and migration influences access to school. Child labour and child migration are not independent of each other. Often, child labour is the pull factor behind child migration. Their influence on schooling is therefore discussed simultaneously.

There are links between poverty and child labour and how that results in children being pulled out of school to work (Hunt, 2008). Other research works (see Admassie, 2003; Canagarajah \& Coulombe, 1997; Ersado, 2005; Huisman et al., 2009) reveal the influence of child labour on schooling. Research by Guarcello et al. (2005) and Jacoby and Skoufias, (1997) reveal that households in developing countries adjust the school attendance and labour force participation of their children to absorb the impact of negative shocks. For instance, in rural settlements, parents facing an unexpected decline in crop income withdraw their children from school (Jacoby \& Skoufias, 1997). Beegle et al. (2006) reported that crop shock leads to a significant increase in child labour and to a decrease in school enrolment and attendance. Guarcello et al. (2005) not only highlight how some households adjust the activity status of children in response to idiosyncratic shocks and natural disasters but also reports that the effects of such shocks on children's activities are often enduring, as children who are sent to work are subsequently less likely to return to school.

Hunt, (2008) shows that the types of work children are engaged in has implications for initial and sustained access to schooling (see also Ersado, 2005). In terms of gender, Hunt, (2008) pointed out that research by Brock \& Cammish, 1997 and Andvig et al. 2001 reveal that in some cultures, the girl child may drop out of school because of demands on her to look after siblings. In certain contexts, child labour may interfere with boys schooling rather than that of girls (see Cardoso \& Verner, 2007; Hunter \& May, 2003). For instance, boys in Ethiopia are likely to be the first to enrol in school, but during periods of economic crisis, they also be the first to withdraw to engage in waged employment (Rose \& Al Samarrai, 2001).

Withdrawing from school to work affects regular school attendance and usually leads to dropout. Colclough et al. (2000) noted that some children enrolled at the beginning of the school year but leave by the middle of term as a result of demands for their labour during harvest time. Such children may re-enrol the following year in the same grade but, again, are unable to complete the year (Colclough et al., 2000). Combining child labour with schooling often leads to incidents of lateness at school and or irregular attendance (Guarcello et al., 2005). In Ghana it was revealed that child labour is the main reason that pupils drop out of school (Fentiman et al., 1999). It is important to note that whatever the form child labour takes, it builds pressure on the children's schooling time. Often, when seasonal activities such as child labour and migration clash with school hours, children who are engaged in such activities terminate their schooling (Hunt, 2008). Hashim, (2005) pointed out that older children (aged 13 and above) from poor rural communities in northern Ghana migrate to wealthier localities in the south in search of employment.

Child migration to work and demands of the labour market influences schooling decisions and dropout patterns (Hunt, 2008). In situations where rural-urban migration exist with opportunities for children to work and earn money, school children often terminate their schooling in order to migrate and find work (Hunt, 2008). Smita (2008) highlights the effects of seasonal migration on educational access in India.

Duryea (2003) found that a buoyant job market acted as the main force pulling children out of school in Brazil. Similarly, Okumu et al. (2008) emphasise how communities can influence dropout rates by providing employment opportunities during school hours. The next section highlights the methodology of the study. It focuses on type of study, the participants, procedure and analysis.

\section{Methodology of the Study}

This study was designed to explore how and why migration shapes school attendance and school dropout. It also aims at giving voice to children to tell their individual experiences of migration and schooling. Accordingly, the qualitative approach is considered invaluable to this study. Qualitative research is committed to seeing the social world and the events that take place in it through the eyes of the researched; its provision for gathering detailed accounts of actions that occur in the setting being explored; and the ready evidence of change and flux it is able to provide (Bryman, 2004). Adopting the qualitative approach for this study is useful for going beyond the surface to the deeper issues about child labour, migration and schooling. The study was therefore designed as a kind of "case study". To Yin (2009), the case study design is an empirical inquiry that investigates a contemporary phenomenon in depth and within its real-life context (Yin, 2009: p. 18). In this paper, I conceived the case study to be nested. It resonated at three levels: first, the phenomenon of seasonal migration to work and school dropout as a case; second, the geographical location of the study is another case; and finally, "case” at particularistic level-the individual experiences of dropout children.

\section{Participants}

This study took place in two of the eight educational circuits in the Mfantseman district in the Central Region of Ghana. Some communities in the Central region are regarded as deprived in Ghana. The district has a total population of 152,264 comprising 69,670 males and 82,594 females who reside in 168 settlements of which 148 are rural. The participants in this study are selected from 2 rural schools located in two different educational circuits-Narkwa and Dominase circuits educational ${ }^{2}$. From Narkwa circuit, one school from the Narkwa community was selected and in Dominase circuit, one school in the Kyeakor community was also selected. In these communities, fishing (in Narkwa community) and subsistence farming, trading are the main occupations. There is also high migration of children from both communities to fishing towns such as Half Assini, Axim, Fasu ${ }^{3}$, and to la Cote d'Ivoire ${ }^{4}$ during major fishing seasons. In terms of socio-economic activity, the selected communities are typical of other communities in the district. The district was selected for the study because of its socioeconomic activities that pose challenge to schooling. Many school children in these communities are overaged in grade. 18

${ }^{2}$ These circuits are located 15 and 20 kilometres respectively from the district capital. The two circuits are approximately 35 kilometres away from each other.

${ }^{3}$ Half Assini, Axim, Fasu are fishing communities in the western region of Ghana. These communities are very close to la Cote d'Ivoire.

${ }^{4}$ Cote d'Ivoire is located in the western border of Ghana. 
children ( 8 girls and 10 boys) aged between 7 and 17 years who dropped out of school participated in the study. Although the study sought to highlight the voices of children, I also interviewed 6 school teachers and 6 parents. In this paper I highlight case studies of the 18 children, who have for different periods of time migrated and dropped out of school.

\section{Procedure}

To identify dropout children to participate in this study, I made initial contacts with some school pupils who attended school irregularly. I also walked in the two selected townships during school hours when school-age children would be expected to be in school to identify children not in school. After contacting a child, I negotiated access by seeking consent from the child's parents and assent from children before engaging them in the study. The first contact with the children who attended school irregularly and those I met loitering in town during school hours led me to identify other children who participated in the study. During the period of data collection, I conducted in-depth interviews with all 18 children who participated in this study. Interviews with the children were unstructured, with episodic interviews and generative narrative questions. I conducted a total of 46 interviews with the children, 36 interviews in the first phase of data collection (twice with all 18 children) and 10 interviews during the second phase. I audio recorded and transcribed all the interviews personally. Also, I examined all the children's past attendance records prior to their dropping out. I gave children disposable cameras to take photographs of activities they engaged in that shape their schooling behaviour. The photographs were very useful in opening conversations with children. I observed activities in the community that children mentioned to have influenced their schooling decisions. To gain first-hand information about seasonal migration and what dropout children do when they migrate, I followed 12 of the children who migrated. The data for this study was collected in two phases within a period of 11 months (between June to October 2008 and October 2009 to March 2010).

\section{Analysis}

A thematic approach to data analysis was adopted, which involved developing themes and patterns from the data (Glasser \& Strauss, 1967; Guba \& Lincoln, 1985).The data I analysed included in-depth interview transcripts, samples of children's profiles and dairies, and field notes. Data from all interviews were analysed manually by making summaries of the views of the participants; supporting them with relevant quotations that captured these views; and augmenting the findings with data from my own field observations. The analysis of data primarily involved an iterative process of reading, reflecting and coding the interview transcripts, and then drawing out major and recurring themes from it. Individual accounts and response to questions were critically examined, categorising responses and finally deriving themes from them. I developed an inductive cyclical diagramme to illustrate clashes between seasonal migration and school calendar founded on children's accounts, analysis of school calendar, parents and teachers views and my observation of periods and lengths of time children migrated and when they return to their communities. For analytical purposes and in terms of children's accounts of how their school- ing was influenced by child labour and seasonal migration, I present the findings and discussion together in the next section.

\section{Findings and Discussion}

The findings and discussion focuses on the child labour activities of children, the reasons children give for migration and how such movements interferes with their schooling. It spans several economic activities of children during school hours and the reasons of child migrants. Issues pertaining to children's migration to work and schooling are highlighted in the discussion. It is important to note that the reasons children cite for working and migrating are not independent of each other; rather, they often exert their influences concurrently, and an understanding of the relative importance of such factors in affecting children's schooling decisions can only be obtained if they are studied simultaneously.

\section{Child Labour and Clashes with School Calendar}

Local labour market opportunities appeared to prompt children to pursue income-generating activities instead of going to school. I noticed that children participated enthusiastically in economic activities in the two study sites, even competing amongst themselves for work in the local and external informal labour markets.

I observed during data collection that the informal labour market structure gave children the opportunity to gain employment by taking part in fishing expeditions and working on farms; as well as to sell various items ranging from farm produce to provisions. It is thus likely that the attraction and accessibility of such an informal labour market structure interrupts children's schooling.

It appears children might have found that they were not able to concentrate fully on their schoolwork because by the age of 9 , it was becoming more difficult to postpone immediate financial reward in order to pursue temporally remote but more valuable academic goals. For example, instead of attending school, some children in Narkwa, particularly boys, joined groups of adults who left home early in the morning to go fishing, or sometimes waited at the beach for the fishing canoes to dock; while a larger number of younger children joined them later in the afternoon when school was over in order to work at the beach. During interviews with children, some of them had this to say about working to raise money:

"I had to support my parents to take care of my brothers and sisters, so I resorted to going fishing and working at the beach... Sometimes, I caught crabs, which I sold to raise money ...That was when I started attending school irregularly."

"Sometimes I don't go to school regularly because I have to work."

"I have been working to make money to buy a new school uniform...so I attended school irregularly."

"During the harvest season, I work at the beach to make money."

These interview excepts no doubt reflects the extent to which children were attracted to seek employment in the informal local labour market instead of going to school. It seems that children from poor socio-economic backgrounds and the indifferent attitude of the community towards schooling were the reasons why some children considered selling their labour to be attractive. Madda, a parent, told me: Because of the money they 
make from fishing activities, some of the children in this village are not willing to stay in school, and most of the adults in this community are not worried that children are not staying in school.

It appears that children's attraction to the informal labour market was supported by covert collective communal support for them to sell their labour. It thus seems that the community condoned dropping out of school and approved of children finding a job. It is likely that such collective communal support created an enabling environment that acted as a driving force, pulling children out of school to sell their labour in the informal labour market. It may be argued that such a collective communal support compromises children's school attendance and that this was the overt manifestation of a structural devaluation of schooling which otherwise is not visible.

For example, upon the arrival of the canoes at around 1:00 $\mathrm{pm}$, all other activity in the Narkwa village ground to a halt and both children and adults converged on the beach to do brisk trade. Some pupils even ran away from school so as not to miss out if the boats docked early. Apparently, adults needed child labour, a point that became clear when Mark told me: We [children] have to be at the beach to help unload the fish, and our parents expect us to bring fish and money home. Joe, another boy also said: when you don't help adults at the beach or work to bring anything (money or fish) home, family members think you are lazy and sometimes your parents refuse to give you food at home.

It can be argued that children absent themselves from school to engage in economic activities because of the existence of a market for child labour. Okumu et al. (2008) reports on a similar phenomenon about how communities influence dropout rates by providing employment opportunities during school hours. Also, Duryea (2003) noted that a buoyant job market acted as the main force that pulled children to drop out of school.

Apparently, the labour market in the study sites shaped children's schooling behaviour and attendance patterns because although most children enrolled, they only attended classes until fishing and farm work were available, after which they dropped out in order to earn money. In effect, this may explain the issue of the seasonality of dropout. An exploration of the attendance records of children who dropped out of school reveal that almost all of them attended school irregularly for at least a month to work prior to dropout. Moreover, it appears that children who previously attended school irregularly, especially to pursue economic activities, easily dropped out of school again. In all of the dropout cases, migrating to work also emerged as a key contributing factor. The next section highlights evidence of the overlap between seasonal migration and school academic calendar in the study area.

\section{Seasonal Child Migration and Clashes with School Calendar}

Seasonal migration came up in my interviews with children as one of the critical factors that pulled children out of school. The effect of seasonal migration on regular school attendance was twofold. On the one hand, parents migrated with their children even before schools broke up for the holidays; and on the other hand, some children independently migrated seasonally to work in other fishing communities.

For some children, drop out occurred because they migrated with their parents. A child's education was disrupted when he or she was withdrawn from school to accompany parents on the seasonal migration. I was told by John, a 14 year-old boy who dropped out of grade 4 that: $I$ was in grade two by then and school hadn't yet vacated, but my mother took me to accompany her to la Cote d'Ivoire; and she left me there with my aunt for eight months. Another child-Ninkyi said: my father took me to the city to go and work with him. That was when I did not go to school for the whole of the first term...I was in grade 5 by then.

From another angle, it appears that older children who did not accompany their parents to migrate before school vacation migrated during the school holidays to join them then, but that such pupils did not return home early enough for the beginning of the new academic year. I observed that boys in the upper primary grades were the most affected category of children whose schooling was disrupted by seasonal migration. Although these older boys migrated during the school holidays, they were often unable to return early enough to register at the beginning of the new academic year and thus continue their schooling. For instance, Emmanuel told me: During the vacation, I travelled to Half Assini to fish, but when school reopened I had not made enough money to go back to school ... So, I travelled further, to the Gambia, in the company of other children to fish. Other children who dropped out due to migration also said:

"I dropped out of school because I travelled to Half Assini to work”.

"By the time I was in grade 4, I travelled to Half Assini during the vacation to fish; but I did not return when school reopened, and I stayed there longer working for money. But when I returned to school, I had problems with school authorities, so I stopped going to school”.

"During the long vacation, I travelled to Half Assini to work there too. I was supposed to enter grade 6 but I did not return from Half Assini early enough. I missed most of the days, so I could not return to school”.

"In the third term, I did not go to school at all because, I travelled early to Half Assini to work. The problem is that when you stop school for some time and you go back, you have problems with the teachers so you just stop going".

Thus, withdrawing from school before the end of term obviously resulted in disruption to a child's schooling. In confirmation of this point, a male teacher, Hamid, explained: Some children drop out of school because their parents migrate with them. In some cases, the child is left behind but they later migrate to join their parents. However, when school reopens, some of these children do not report early and this disrupts their schooling.

For most children in the study area, seasonal migration began in mid-June, that is, about five weeks before the end of the third term (see Figure 1). Children who migrated often stopped attending classes at this point.

Figure 1 illustrates the clash between school times and seasonal migration, which provide evidence that corroborate other studies on seasonality (see Smita, 2008; Hadley, 2010). In addition, Akyeampong et al., (2007) noted that migration habits of children have implications for school attendance in Ghana (see also, Fentiman et al., 1999).

The period of migration in the third term was the time of the school year when children sat their graduation examinations; thus, non-participation in such assessment meant grade repeti- 


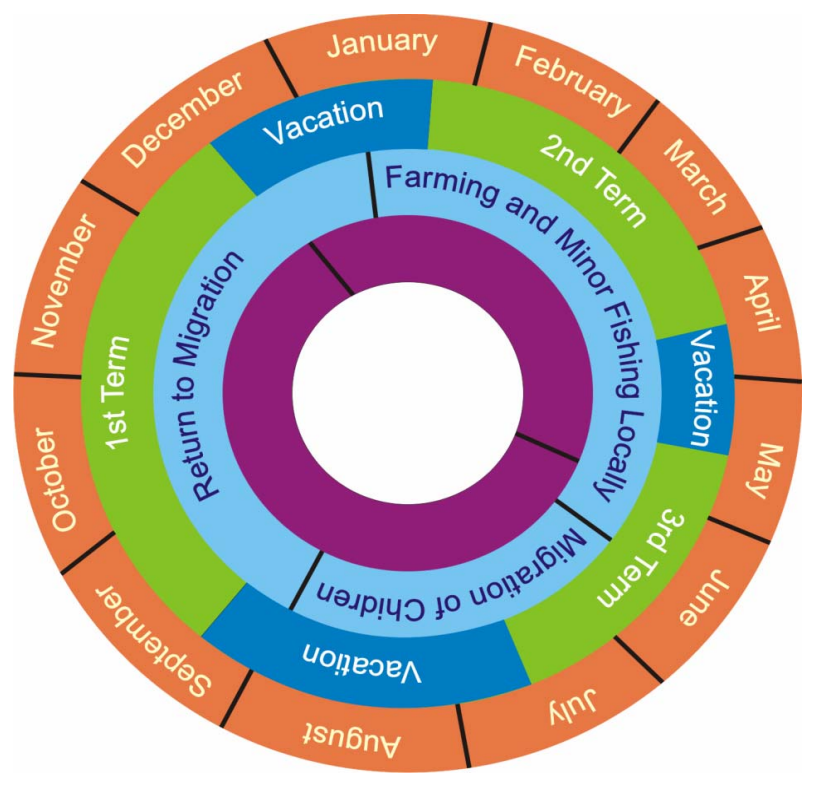

Figure 1.

School Calendar, Migration Calendar and Economic Activities of School Children. (Source: Field data)

tion. Therefore, in addition to late enrolment, it is probable that seasonal migration partly explained the cases of overage in grade, given that grades were most frequently repeated in lower primary school.

Taking the duration of the third term as being from May to July, and the beginning of the first term as being in early September into consideration, it appears that seasonal migration from mid-June to early October might have been largely responsible for dropout cases. It could be argued that the clash between the school calendar and seasonal migration created recurrent cases of irregular attendance and school dropout during the academic year. In the cases of children engaged in this study, it seems that the influence of seasonal migration on their schooling was so strong that some pupils' education spanning two academic years was punctuated by irregular attendance and subsequent dropout.

Considering activities such as child labour and seasonal migration, disruption of school attendance could be overcome if the schools adapted their timetables to it. When teachers were asked why the school calendar could not be adapted to accommodate this inevitable seasonal activity. One female teacher told me: All schools in Ghana follow the same timetable for reopening, writing exams and holidays...We don't have the authority to change any aspect of the school calendar.

It seems no provision exists to allow for adjustment to the school calendar in order to suit local variations in seasonal activities that potentially disrupted school attendance. In my informal discussion with the Parent Teacher Association (PTA) chairperson and a school management committee (SMC) member, they told me that they wished they had the power to change the school times in order to avoid clashes with harvest periods. They believe that such changes may be useful in ensuring that schoolchildren remain in school. Research shows that among the factors that are responsible for low educational access and dropout is rigid schooling system, which does not cater for particular needs of local communities such as seasonal migration out of communities (Care International 2003).

\section{Conclusion}

I have shown in this paper that the phenomenon of child labour, seasonal child migration, and school dropout in the study areas involve clashes in school calendar and activities. The clashes between seasonal child migration and school calendar in the study area have a lot of challenges for children's progression and completion of schooling. Many of the migrant children miss out on their learning when they miss school as a result of migration to work in the informal labour market. In return, they perform poorly in school and are therefore repeated. Thus they become over age in grade, while repeating they tend to attend school irregularly, and migrate again.

This study has shown that the clashes in seasonal child migration and school calendar in Ghana have created a path for some children living in such communities to drop out of school. It is therefore important that policies and programmes are evolved to ensure that the risks involved in the migration of these children are reduced.

Considering the foregoing, I highlight some policy implications to be considered. First, in respect of the clash between the organisation of the academic year and the seasonal activities that pull children out of school, policy on the school calendar should be reformed and adapted to the requirements of local activities. Secondly, school curricular may have to be rearranged to accommodate seasonality of school attendance. For instance, more intensive teaching should be done during such periods that children were not likely to migrate or work. Thirdly, remedial lessons should be organised for children who return to school long after schools have reopened. Lastly, alternative school programmes might be useful in providing courses for dropout children who were overage on withdrawal, and those for whom schooling had lost its value but might yet be willing to improve their literacy and numeracy skills.

It is important to know that the evidence presented in this report is important but it has some limitations to it. First this study is only limited to the selected cases of migrating children in a rural setting with whom I was able to negotiate access. Secondly, the interviews were conducted in the local languageFante-before transcribing and translating them in English. Notwithstanding my proficiency in Fante, the translation process might still have led to a loss of meaning to a certain extent, which could have negatively affected the quality of the information I have presented.

\section{REFERENCES}

Admassie, A. (2003). Child labour and schooling in the context of a subsistence rural economy: Can they be compatible? International Journal of Educational Development, 23, 167-185. doi:10.1016/S0738-0593(02)00012-3

Akyeampong, A. K., Djangmah, J., Oduro, A., Seidu, A., \& Hunt, F. (2007). Access to basic education in Ghana: The evidence and the issues. Consortium for Research into Educational Access Transition and Equity (CREATE), Country Analytic Review. Brighton: University of Sussex.

Ampiah, G., \& Adu-Yeboah C. (2009). Mapping the incidence of school dropouts: A case study of communities in northern Ghana. Comparative Education, 45, 219-232. doi:10.1080/03050060902920625

Ananga, E. D. (2011). Typology of dropout: The dimensions and dynamics of dropout in Ghana. International Journal of Educational Development, 31, 374-381. doi:10.1016/j.ijedudev.2011.01.006

Andvig, J., Canagarajah, S., \& Kielland, A. (2001). Issues in child labour in Africa, human development sector Africa region. Working 
Paper, Washington DC: World Bank.

Brock, C., \& Cammish, N. (1997). Factors affecting female participation in education in seven developing Countries. Educational Paper No. 9 DFID, London.

Buchmann, C., \& Brakewood, D. (2000). Labor structure and school enrollments in developing societies: Thailand and Kenya compared. Comparative Education Review, 44, 175-204. doi:10.1086/447602

Canagarajah, S., \& Coulombe, H. (1997). Child labor and schooling in Ghana: Labor markets and poverty. Washington DC: World Bank.

Cardoso, A. R., \& Verner, D. (2007). School drop-out and push-out factors in Brazil: The role of early parenthood, child labor, and poverty. IZA Discussion Paper No 2515, Bonn: Institute for the Study of Labour (IZA).

Care International (2003). Reaching underserved populations with basic education in deprived areas in Ghana: Emerging good practices. Washington DC: USAID.

Colclough, C. Al-Samarrai, S. Rose, P., \& Tembon, M. (2003). Achieving schooling for all in Africa. England: Ashgate.

Colclough, C., Rose, P., \& Tembon, M. (2000). Gender inequalities in primary schooling: The roles of poverty and adverse cultural practice, International Journal of Educational Development, 20, 5-27. doi:10.1016/S0738-0593(99)00046-2

Dumas, C., Glick, P., Lambert, S., Sahn., D., \& L. Sarr. (2004). Progression through school and academic performance in Senegal: Descriptive survey results. Working Paper, Washington DC: World Bank.

Duryea, S. (2003). School attendance, child labor and local labor market fluctuations in Urban Brazil. World Development, 31, 1165-1178. doi:10.1016/S0305-750X(03)00065-2

Ersado, L. (2005). Child labor and schooling decisions in urban and rural areas: Comparative evidence from Nepal, Peru, and Zimbabwe. World Development, 33, 455-480. doi:10.1016/j.worlddev.2004.09.009

Edmonds, E., \& Shreta, M. (2009). Children's work and independent child migration: A critical review. Innocenti Working Paper, No. 2009-19, Florence: UNICEF.

Fentiman, A., Hall, A., \& Bundy, D. (1999). School enrolment patterns in rural Ghana: A comparative study of the impact of location, gender, age and health on children's access to basic schooling. Comparative Education, 35, 331-349. doi:10.1080/03050069927865

Ghana Statistical Service (GSS) (2003). Ghana child labour survey. Accra: Ghana.

Guarcello, L., Lyon, S., \& Rosati, F. (2005). Impact of Children's Work on School Attendance and Performance: A Review of School Survey Evidence from Five Countries. Understanding Children's Work; UCW-SIMPAC Working Paper March 2005, An inter-agency research co-operative project. ILO, UNICEF, World Bank. Geneva.

Hadley, S. (2010). Seasonality and access to education: The case of primary education in sub-Saharan Africa. Consortium for Research into Educational Access Transition and Equity (CREATE), Working Paper No. 31. Brighton: University of Sussex.

Hashim, I. M. (2004). Working with working children: Child labour and the barriers to education in rural North-Eastern Ghana. Ph.D. Thesis, Brighton: University of Sussex.

Hashim, I. M. (2005). Exploring the linkages between children's inde- pendent migration and education: Evidence from Ghana, DRC on migration, globalization and poverty. Brighton: University of Sussex.

Hashim, I. M. (2006). The positive and negatives of children's independent migration. Working Paper: Centre for Migration Research, Sussex University.

Hunt, F. (2008). Dropping out from school: A cross country review of literature. Consortium for Research into Educational Access Transition and Equity (CREATE), Working Paper No. 16. Brighton: University of Sussex.

Hunter, N., \& May, J. (2003). Poverty, shocks and school disruption episodes among adolescents in South Africa. Centre for Social and Development Studies Working Paper, No. 35. Durban: School of Development Studies, University of Natal.

Huisman, J., \& Smits, J. (2009). Keeping children in school: Household and district level determinants of school dropout in 322 districts of 30 developing countries. Nijmegen Center for Economics (NiCE) Working Paper, No. 09-105. Nigmejen: Radboud University

ILO/IPEC (2004). Helping hands or shackled lives? Understanding child domestic labour and responses to it. Geneva: ILO.

Jacoby, H. G., \& Skoufias, E. (1997). Risk, financial markets, and human capital in a developing country. Review of Economic Studies, 64, 311-335. doi:10.2307/2971716

Lewin, K. M. (2007). Improving access, equity and transitions in education: Creating a research agenda. Consortium for Research into Educational Access Transition and Equity (CREATE), Working Paper No. 1. Brighton: University of Sussex.

Ministry of Education Science and Sports (2005). Preliminary education sector performance report. Accra: Ministry of Education.

Ministry of Education Science and Sports (2006). Preliminary education sector performance report. Accra: Ministry of Education.

Ministry of Education Science and Sports (2007). Preliminary education sector performance report. Accra: Ministry of Education.

Ministry of Education Science and Sports (2008). Preliminary education sector performance report. Accra: Ministry of Education.

Okumu, I. M., Nakajjo, A., \& Isoke, D. (2008). Socio-economic determinants of primary school dropout: the logistical model analysis. http://www.http:/mpra.ub.unimuenchen.de/7851/

Rosati, F, C., \& Rossi, M. (2007). Impact of School Quality on Child Labour and School Attendance: The Case of CONAFE Compensatory Education Program in Mexico. Understanding Children's Work (UCW) Working Paper, February 2007, An inter-agency research co-operative project. Geneva: ILO, UNICEF, World Bank.

Rose, P., \& Al-Samarrai, S. (2001). Household constraints on schooling by gender: Empirical evidence from Ethiopia. Comparative Educational Review, 45, 3-63. doi:10.1086/447644

Smita (2008). Distress seasonal migration and its impact on children's education. CREATE pathways to access research monograph No. 28. Brighton: University of Sussex.

PROBE (1999) Public report on basic education in India. The PROBE Team, Oxford: Oxford University Press.

Wikan, G. (n.d.). Non-enrolled, drop-outs and pupils: The state of education for all in Namibia.

http://www.pef.uni-lj.si/978-961-6637-06-0/261-269.pdf 